NBER WORKING PAPER SERIES

\title{
ACCOUNTING FOR RACIAL DIFFERENCES IN SCHOOL ATTENDANCE IN THE AMERICAN SOUTH, 1900: \\ THE ROLE OF SEPARATE-BUT-EQUAL
}

\author{
Robert A. Margo
}

Working Paper No. 2242

\section{NATIONAL BUREAU OF ECONOMIC RESEARCH 1050 Massachusetts Avenue \\ Cambridge, MA 02138 \\ May 1987}

The research reported here is part of the NBER's research program in Development of the American Economy. Any opinions expressed are those of the author and not those of the Nationa 7 Bureau of Economic Research. 
NBER Working Paper \#2242

May 1987

Accounting for Racial Differences in School Attendance

In the American South, 1900: The Role of Separate-But-Equal

\section{ABSTRACT}

Everyone knows that public school officials in the American South violated the Supreme Court's separate-but-equal decision. But did the violations matter? Yes, enforcement of separate-butequal would have narrowed racial differences in school attendance in the early twentieth century South. But separate-but-equal was not enough. Black children still would have attended school less often than white children because black parents were poorer and less literate than white parents.

Robert A. Margo

Department of Economics

Colgate University Hamilton, NY 13346

(315): 824-1000, ext. 520 
In Plessy vs. Ferquson (1896) the supreme Court ruled that racially separate-but-equal public institutions, such as schools, were constitutional. Everyone knows that school officials in the American South violated the equal part of the ruling. " Evidence linking the violations to educational outcomes, however, has been studied less often. An analysis of school attendance patterns in the South in 1900 shows that enforcement of separate-but-equal would have raised the frequency of school attendance by black children compared with white children. But poverty and high rates of adult illiteracy ensured that black children still would have attended school less often than white children even if separate-but-equal had been enforced.

1. School Attendance in the American South, 1900

In 1900 the 46 percent of southern children between the ages of 5 and 20 who attended school went for an average of 89 days, 10 days longer than the average days attended by the 30 percent of southern black children in school (U.S. Bureau of the Census, $19023, p p .352-383)$. Compounded over childhood the racial

differences in school attendance had predictable effects. In 191024 percent of southern blacks between the ages of 15 and 24 were iliterate, compared with 6 percent of southern whites (U.S. Eureau of the Census, 1918, pp. 412-418).

Why were racial differences in school attendance so large in the South at the turn of the century? For W.E.B. Du Bois and 
Augustus Dill (1911, P. 137; see also Ransom and Sutch, 1977, pp. 27-30) the answer was educational discrimination. School officials in the south allocated fewer resources to black schools than to white schools which, in turn, reduced the frequency of school attendance among black children compared with white children. Had the equal part of separate-but-equal been enforced the quantity and quality of black schools would have been greater and racial differences in school attendance smaller.

How much smaller? Step one is to specify a model of school attendance. My model is:

$$
\underline{A}=\beta_{m}+\beta_{n} \underline{x}_{m}+\beta_{c=} \underline{x}_{n}=+\beta_{m} \underline{x}_{m}+\beta_{m} \underline{x}_{m}+e
$$

The child is the unit of observation. A measures the frequency of school attendance by the child, $\underline{x}_{m}$ is a vector of characteristics of the child's parents, $\underline{x}_{=}$is a vector of characteristics of the child, $\underline{x}_{m}$ is a vector of public school characteristics, $\underline{x}_{0}$ is a vector of geographic characteristics, the $\beta$ 's are coefficients, and $e$ is an error term.

Think of equation [1] as the outcome of a household utility maximization (see Goldin, 1979). Parents derive utility from the consumption of market goods and home production by household members and from their children's schooling. They allocate their children's time between schooling and other activities, such as work at nome or in the market. How frequently a child attends school depends on the characteristics of the parents and the 
child; on the availability of schooling, quantity and quality; and on the returns to schooling compared with other uses of the child's time, which may vary with the household's location. A household model is appropriate for the early twentieth century South. The economy was agricultural and children were productive workers. Most schooling was at an elementary level, completed before the child left home. Southern legislators did not pass compulsory schooling laws until after the turn of the century and the laws were poorly enforced (Landes and Solmon, 1972).

Step two is to estimate equation [1]. The sample is 2,020 southern children between the ages of 5 and 16 . The data source is the public use sample of the 1900 census. 2 The dependent variable is the number of months of school attended in the census year. Because many children did not attend school the dependent variable is censored at zero, and Tobit analysis is used.

Sample means and standard deviations of the dependent and independent variables are shown in Table 1. On average, black children attended 1.3 months of school, 1.1 months fewer than white children. Although racial differences in child characteristics were small, there were large racial differences in the characteristics of parents, public schools, and household location. Black parents were less literate than white parents, and had lower incomes and wealth, as measured by the occupational status of the household head and homeownership. Compared with public schools for white children, the black schools were fewer in number, school terms were shorter, class sizes larger, and 
teacher salaries lower. Black families were more likely to live where cotton was the major crop, where plantation agriculture was practiced (see below), or in or near an urban area.

The tobit coefficients are shown in Table 2 . Separate equations were estimated for black and white children. Broadly speaking, the results affirm the model described by equation [1]. If a child's education were a normal good school attendance should increase with parents' income and wealth. As noted above, occupational status and homeownership are proxies for income and wealth. Literacy and the ages of the parents control for human capital characteristics associated with higher incomes and wealth. Table 2 confirms the hypothesis for occupational status, nomeownership, Iiteracy, and among white children, father's age. Black children also attended school more frequently if their mother was older. The age effect persists when mother's labor force status is included (not shown), which suggests older black mothers may have been more experienced at child rearing or more aware of the economic benefits of educating their children.

school attendance varied with the child's age. The positive coefficient on age reflects differences in the age of entering school (typically between ages o and 9 ). 4 Most children had left school by age 15 or 16 , which explains the negative coefficient on age squared. Unlike age, the child's gender had no significant effect on school attendance. The presence of a child under age 5 in black families lowered school attendance among older siblings, presumably by increasing parental demands on the 
siblings' home time.

The school variables capture various aspects of the quantity and quality of public schools."s School density--the number of schools per 1000 children--and the length of the school year are quantity variables. As school density rises the costs of getting to school fall and school attendance should rise. The longer schools are open the more months a child could attend. The teacher-pupil ratio and the average teacher salary measure the quality of schooling. As the number of teachers per pupil rises classrooms are less crowded. Average teacher salary is a proxy for the human capital of teachers: better trained teachers recieved higher salaries (see Margo, 1984). The coefficients of all four school variables should be positive.

The limitations of the school variables are numerous. The variables are averages for the household's county of residence iri 1900, so the effects of variations within counties are obscured.0 The variables are measured incorrectly for households that moved across county boundaries during the census year. The measure of school density is a crude proxy in sparsely populated counties, or where black and white families were residentially dispersed instead of segregated.7 There are no direct measures of parent's tastes for schooling in the regressions. Parents who placed a high value on schooling may have moved where schools were close by and better in quality. The coefficients of the school variables would be biased since the omitted "tastes" for schooling would be correlated with the school variables."3 
Given the criticisms it is reassuring that 7 of the 8 coefficients have correct signs. School density is the exception: its coefficient is negative in the black equation and statistically insignificant for both races. $\Rightarrow$ Longer school terms and smaller class sizes would have encouraged children of both races to attend school more frequently, but the effect was larger among blacks. Better-trained teachers also would have increased attendance in the black schools.

The geographic variables--percentage of improved acreage in cotton, whether the household lived where plantation agriculture was practiced, and whether the household Iived in or near an urban area--capture variations in the returns to schooling compared with other uses of the child's time. so School officials believed that cotton and schooling didn't mix. "Whole families," wrote a school superintendent from Georgia, "are reared without ever seeing the inside of a school. They are kept at work in the cotton fields."1 1 cotton cultivation went hand-in-hand with plantation agriculture, in which tenant farmers operated small plots under the supervision of a single landlord (U.S. Bureau of Census, 1916). According to Charles Johnson (1934, p. 129) "[1]iteracy was not an asset in the plantation economy" and school attendance was discouraged. By contrast, the returns to schooling were higher in or near urban areas, and children had fewer employment opportunities. An increase in cotton cultivation or residence in a piantation county did reduce school attendance, but the effects were statistically insignificant for 
both races.12 Urban children of both races, however did attend school significantly longer than rural children, but the effect was larger among blacks.

2. Separate-But-Equal and Racial Differences in School Attendance

Evidently Du Bois and Dill were right: the characteristics of public schools did affect black school attendance. Table 1 demonstrated there were significant racial differences in school characteristics in the sample. How much smaller would racial differences in school attendance have been if racial differences in school characteristics were reduced to zero, that is, if separate-but-equal had been enforced?

The answer is in Table 3 , which gives the percentages of the mean racial difference in school attendance explained by mean racial differences in the independent variables. The notes to Table 3 describe the procedure for calculating the percentages. The percentages in the column labelled Black Equation are based on the black tobit coefficents and the percentages in the column labelled White Equation on the white tobit coefficients.

Racial differences in school characteristics account for 44 to 49 percent of the racial difference in months attended. Clearly, had separate-but-equal been enforced black children would have attended school more of ten. But black attendance still would have been less than white attendance because of racial differences in parents' characteristics. Indeed, had black and 
white parents the same average characteristics the mean racial difference in school attendance would have been cut by 63 to 72 percent, even without enforcement of separate-but-equal. Racial differences in literacy alone explain 41 to 49 percent of the racial difference in school attendance. Racial differences in child and geographic characteristics were far less important, however, accounting for 7 to 18 percent of the racial difference in school attendance.

studies of racial differences in earnings show the returns to schooling in the South were lower among blacks than whites for most of the twentieth century (Smith and Welch, 1986). Were the racial differences in returns to schooling solely a reflection of racial discrimination in labor markets, black children would have attended school less frequently than white children, other things equal. The row labelled Total Explained, however, shows that racial differences in the independent variables can explain all of the racial difference in school attendance. Race per se was not why black attendance was less than white attendance. Whatever the reason for racial differences in the returns to schooling, the differences were not an independent cause of the racial differences in school attendance. $x: y$

\section{Concluding Remarks}

I have examined one way educational discrimination in the past affected educational outcomes. Enforcement of the Supreme 
Court's separate-but-equal decision would have narrowed the racial difference in school attendance in the South in 1900. But separate-but-equal was not enough. Black children still would have attended school less often because their parents were poorer and less literate than white parents.

By 1930 racial differences in school attendance rates in the South fell to 9 percentage points overall (see U.S. Bureau of the Census, 1943). Why did the racial difference in school

attendance decline? Are changes in parent's characteristics or household location responsible? Did the effects of seperate-butequal increase or decrease over time? An analysis of census data from 1910 to 1930 using the framework developed here should help answer the questions.14 


\section{FOOTNOTES}

* Department of Economics, Colgate University and National Bureau of Economic Research. I am grateful to Susan Carter, claudia Goldin, David Gray, Richard Steckel, Paul Taubman, seminar participants at Harvard University and the Washington Area Economic History Workshop, and three referees for helpful comments. All errors are my own.

1. For evidence see Margo (1985).

2. The 1900 census sample is a nationally representative sample of the population of the United States in 1900. The sample is made up of 27,609 households containing 100,438 individuals, or approximately 1/760th of the U.S. population in 1900. The data were originally collected by the Center for studies in Demography and Ecology, University of Washington, and were made available to me by the Inter-University Consortium for Political and Social Research, University of Michigan.

3. In families headed by females the head's occupational status, age and literacy are the mother's. Because occupational status and homeownership are only proxies, the true effects of income and wealth on school attendance land the true racial differences in income and wealth) were undoubtedly larger. If so, the effects of separate-but-equal (see Table 3 ) are biased upwards. 4. Months attended did not vary by age among children in school. Thus the significant age effect in the regressions reflects variations in the ages of entering and leaving school. 
5. The school variables are available for four states in 1900: North and South Carolina, Alabama, and Florida. Observations from the states make up the sample. The per capita wealth of the county was also tried as a measure of school quality. The variable was always insignificant, however, and was excluded from the final runs.

6. Information on the variance in school characteristics within counties is not available for the sample from published sources. Data for Virginia in 1890, however, suggest the variance across counties was much larger. For example, the variance within counties of the length of the school year in black schools was a third of the variance across counties calculated from data in Superintendent of Public Instruction, State of Virginia (1890)).

7. The number of children per square mile adjusts for the sparsity of population. The variable was always insignificant, however, and was excluded from the final runs.

8. That is, the school variables would be endogenous. Because the coefficients of the school variables would be biased upwards the effects of separate-but-equal (see Table 3 ) would be overstated. Since the point is that separate-but-equal cannot explain all of the racial difference in school attendance the conclusions are the same.

9. It is hard to believe that school density had no effect on school attendance. Most southern children attended one-room schools taught by a single teacher. Variations in the teacherpupil ratio (which has a positive and significant coefficient in 
both equations) may capture the effects of school density in addition to the effects of classroom crowding.

10. The geographic variables refer to the household's county of residence in 1900. A family resides in or near an urban area if its county of residence contains at least one urban place with population greater than 10,000 .

11. Quoted in Superintendent of Public Instruction, State of Georgia (1907, P. 113).

12. If children aged $17-20$ are added to the sample the coefficients of the cotton share are significantly negative for both races, which suggests the effects of cotton cultivation were concentrated among older children.

13. Alternatively, labor market discrimination did make the returns to schooling lower for blacks but black parents valued their children's education more at the margin than white parents. 14. A census sample for 1910 is under preparation at the University of Pennsylvania. The manuseript censuses of 1920 and 1930 are not yet open to scholars, but will be in the future. 


\section{REFERENCES}

Du Bois, W.E.B. and Augustus Dill, The Common School and the Negro American (Atlanta: Atlanta University Press, 1971). Goldin, Claudia, "Household and Market Production of Families in a Late Nineteenth Century American City," Explorations in Economic History 16 (April, 1979), 111-131.

Johnson, Charles, Shadow of the Plantation CChicago: University of Chicago Press, 1934).

Landes, William and Lewis Solmon, "Compulsory Schooling Legislation: An Economic Analysis of Law and Social Change in the Nineteenth Century," Journal of Economic History 32 (March, 1972), 54-91.

Madalla, G.S., Limited-Dependent and Qualitative Variables in

Econometrics (New York: Cambridge University Press, 1983). Margo, Robert A., "'Teacher Salaries in Black and White': The South in 1910," Explorations in Economic History 21 ( July, 1984), 306-326. , Disfranchisement, School Finance, and the

Economics of Segreqated Schools in the United States South, 1890-1910 (New York: Garland Press, 1985 ).

Ransom, Roger and Richard Sutch, Qne Kind of Freedom: The Economic Consequences of Emancipation (New York: Cambridge University Press, 1978).

Smith, James and Finis Welch, "Closing the Gap: Forty Years of Economic Progress for Blacks," Report R-3330-DOL (Santa 
Monica: The Rand Corporation, February, 1986).

Superintendent of Public Instruction, State of Alabama, Annual

Report (Montgomery: State Printer, 1900).

Superintendent of Public Instruction, State of Florida, Annual

Report (Tallahassee: State Printer, 1900).

Superintendent of Public Instruction, State of Georgia, Annual

Report (Atlanta: State Printer, 1907).

Superintendent of Public Instruction, State of North Carolina,

Annual Report (Raleigh: State Printer, 1900).

Superintendent of Public Instruction, State of South Carolina,

Annual Report (Columbia: State Printer, 1900).

Superintendent of Public Instruction, State of Virginia, Annual

Report (Richmond: State Printer, 1890).

U.S. Bureau of the Census, Twelth Census of the United

States: Population, Part Two (Washington: USGPO, $1902 a$ ).

, Twelth Census of the United States:

Agriculture, Parts One and Two (Washington: USGPo, 1902b). , Plantation Farming in the United

States (Washington: USGPO, 1916).

- Sixteenth Census of the United States:

1940, Population, Volume II: Characteristics of the

Population, Parts $1-7$ (Washington: USGPO, 1943). 
Table 1

Sample Means and Standard Deviations: Southern Children in 1900

\begin{tabular}{|c|c|c|c|c|}
\hline Characteristics & $\mathrm{Bla}$ & & & \\
\hline of: & Mean & S.D. & Mean & S.D. \\
\hline Head of Household: & & & & \\
\hline & 11.9 & 5.6 & 18.3 & 17.1 \\
\hline $\begin{array}{l}\text { Percent literate: } \\
\text { Age (in years): }\end{array}$ & 0.49 & 0.50 & 0.84 & 0.37 \\
\hline $\begin{array}{l}\text { Age (in years): } \\
\text { Percent homeowner: }\end{array}$ & $\begin{aligned} 44.0 \\
0.27\end{aligned}$ & 10.7 & 43.8 & 8.1 \\
\hline Spouse: & U. & 0.44 & 0.01 & 0.47 \\
\hline $\begin{array}{l}\text { Percent literate: } \\
\text { Age: }\end{array}$ & 0.38 & 0.48 & 0.78 & 0.41 \\
\hline $\begin{array}{l}\text { Age: } \\
\text { Child: }\end{array}$ & 35.8 & 11.7 & 36.5 & 11.7 \\
\hline $\begin{array}{l}\text { Months of schooling } \\
\text { (dependent variable): }\end{array}$ & 1.3 & 2.2 & 2.4 & 3.0 \\
\hline Age: & 10.4 & 3.4 & 10.3 & 3.4 \\
\hline $\begin{array}{l}\text { Percent female: } \\
\text { Percent households }\end{array}$ & 0.48 & 0.50 & 0.49 & 0.50 \\
\hline $\begin{array}{l}\text { with child under age } 5 \text { : } \\
\text { School: } \\
\text { Schools per } 1000\end{array}$ & 0.25 & 0.43 & 0.32 & 0.46 \\
\hline $\begin{array}{l}\text { Children: } \\
\text { Length of school year }\end{array}$ & 6.9 & 2.9 & 11.9 & 4.9 \\
\hline $\begin{array}{l}\text { in months: } \\
\text { Teachers per } 100\end{array}$ & 4.1 & 1.0 & 4.4 & 1.0 \\
\hline $\begin{array}{l}\text { pupils: } \\
\text { Average monthly teacher }\end{array}$ & 2.7 & 0.8 & 3.6 & 0.9 \\
\hline $\begin{array}{l}\text { salary ( } 1900 \text { dollars): } \\
\text { Geography: } \\
\text { Cotton Acreage/ }\end{array}$ & 22.83 & 4.5 & 29.41 & 6.3 \\
\hline $\begin{array}{l}\text { Improved Acreage } \\
\text { Percent living in }\end{array}$ & 0.28 & 0.16 & 0.20 & 0.15 \\
\hline $\begin{array}{l}\text { Plantation county } \\
\text { Percent living in or }\end{array}$ & 0.60 & 0.49 & 0.46 & 0.50 \\
\hline near urban area: & 0.21 & 0.41 & 0.15 & 0.36 \\
\hline
\end{tabular}

Sources: Parent's and Child Characteristics, "In or near urban area": 1900 Census Public Use sample; School: Superintendent of Public Instruction, States of Alabama (1900), Florida (1900), North Carolina (1900) and South Carolina (1900), and U.S. Bureau of Census (1902a); "Cotton Acreage/Improved Acreage": U.S. Bureau of Census (1902b); "Plantation County": identified from county maps in U.S. Bureau of Census (1916). 
Table 2

Tobit Coefficients: Southern Children in 1900

Black White

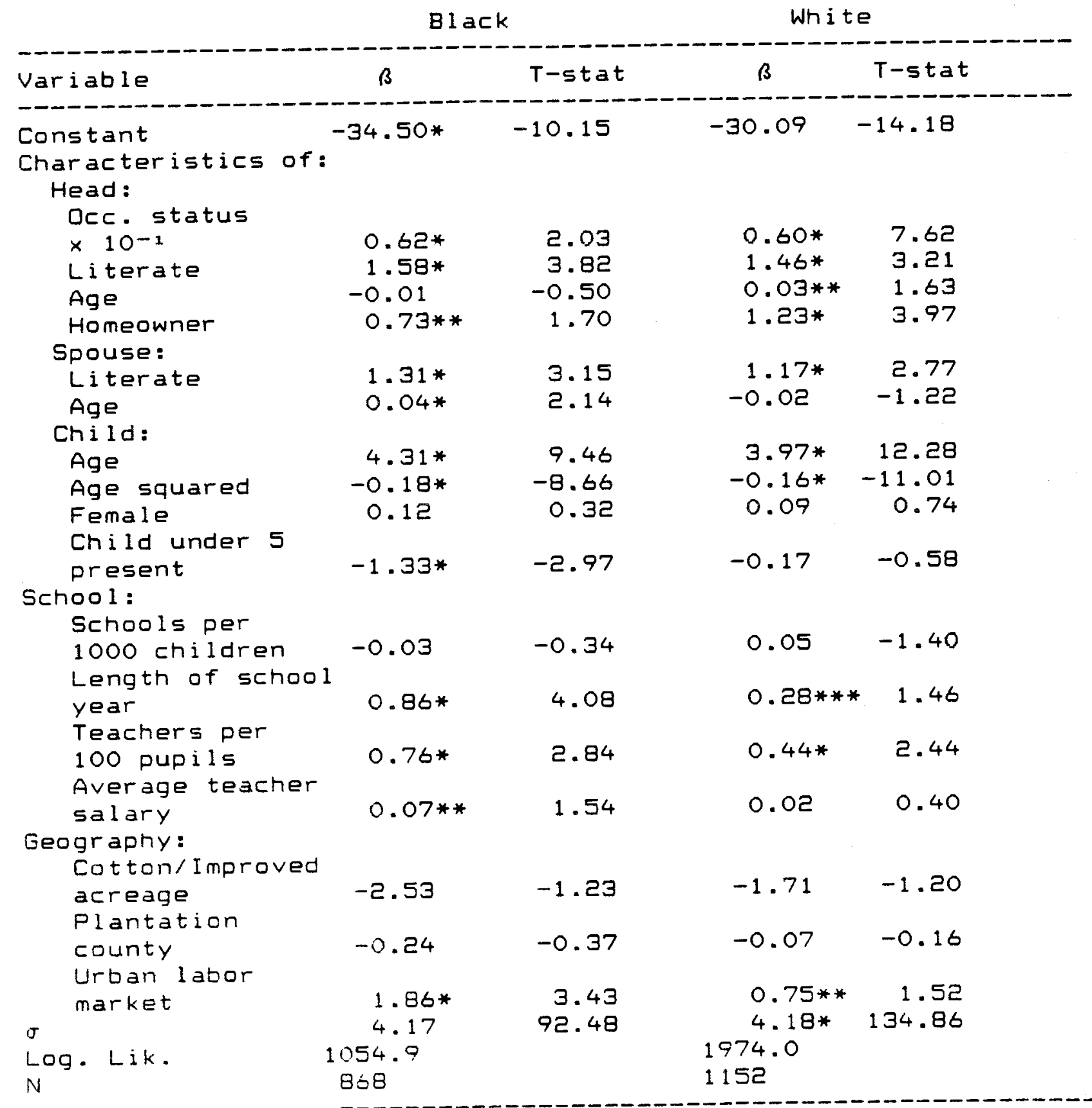

$A$ " * indicates statistical significance: $5 \%$ level (*), $10 \%(* *)$, $15 \%$ (***). Sources: see table 1 . 
Table 3

\section{Accounting for Racial Differences \\ In School Attendance \\ (shown in percent $x 100$ )}

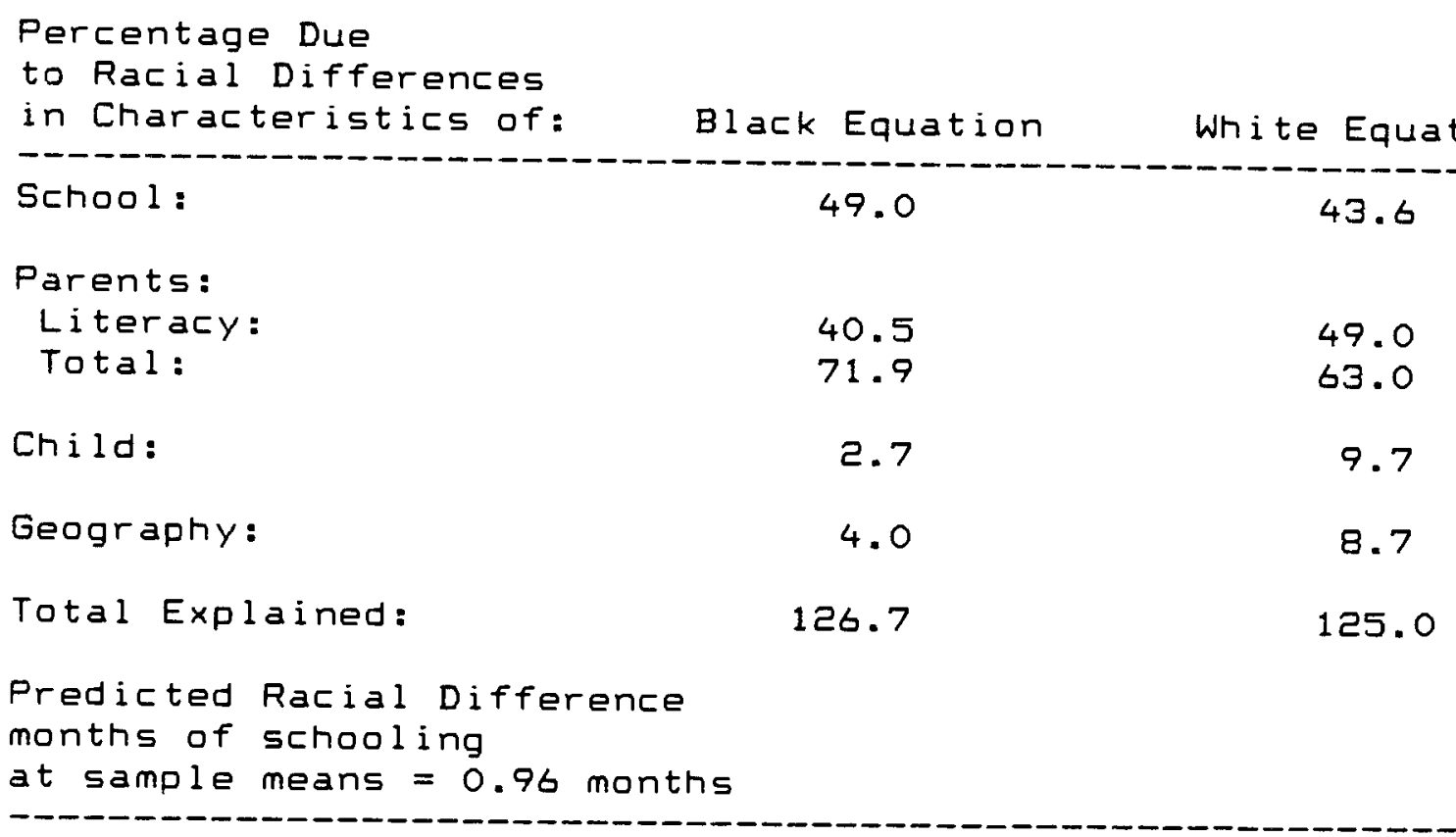

To calculate the percentages I use the tobit coefficients to predict for each race the number of months of school at tended at the race-specific sample means of the independent variables: $\mathrm{m}(\mathrm{b})$ and $m(w), b=b l a c k, w=w h i t e$. Next, I use the black coefficients to predict the number of months a black child would attend at the white sample means, $m *(b)$, and the white coefficients to predict the number of months a white child would attend at the black sample means, $m * w)$. The percent explained is either $(m *(b)-m(b) /(m(w)-m(b))$ [the column labelled Black Equation] or $(m(w)-m *(w)) /(m(w)-m(b))$ [the column labelled White Equation]. The formula for the predictions is given in Madalla (1983, $p$. 159). 